\title{
Kaj Thanings Grundtvigtolkning
}

\author{
Af Harry Aronson
}

Inom Grundtvigforskningen har fastställandet av »märkesår« i anslutning till beskrivningen av Grundtvigs utveckling spelat en stor roll. Man kan efterhand också tala om märkesår i Grundtviglitteraturen. Året ${ }_{196} 6_{3}$ kommer för lång tid framåt att vara ett märkesår i Grundtviglitteraturen: Sognepræst Kaj Thaning presenterade och försvarade en överväldigande dokumentation för sin tes om att 1832 är vändpunkten i Grundtvigs liv och författarskap. Huvudtesen har länge varit känd, genomförandet på ett stort material (tryckt och otryckt) är emellertid nytt och delvis överraskande.

Alla som arbetat med idéhistorisk forskning måste beundra Thanings förmåga att $\mathrm{i}$ ett kvarts sekel fasthålla en tes och ständigt konfronteras med nytt material och nya forskningsresultat. Vi som arbetat med Grundtvig har länge väntat på boken, har brottats med Thanings "tes" och hans Grundtvigtolkning i stort i enlighet med denna. Det har varit ett mödosamt företag att bedöma innebörden däri, just därför att Thanings offentliggöranden före $196_{3}$ varit prefabrikationer från en forskningsverkstad, där arbete alltjämt pågick. Inte sällan väckte "tesen" irritation. Man begärde dokumentation. Den har nu kommit.

Att läsa boken är att följa Thanings arbete $\mathrm{i}$ forskningens verkstad. Hans arbetsförmåga måste beundras. Hans arbetssätt måste kritiseras. - Eftersom kritiken i fortsättningen blir vittgående, är det på sin plats att först framhäva Thanings förtjänster. Först måste då sägas såsom något helt självklart, att mannen bakom programmet "Menneske først" såväl genom sin personliga som sin litterära verksamhet i Grundtvigforskningens tjänst gjort utomordentliga insatser. Ingen kan i fortsättningen tolka Grundtvig utan att röra vid Thaning. Hans opus magnum har fått en inre och yttre form, som tvingar till "opgør". Själv inbjuder han till antingen motstånd eller underkastelse. En uppgift för nästa generation Grundtvigforskare blir att bryta dessa 
förväntningar och intaga en mera mogen hållning. Först därigenom kan forskningen sakligt föras framåt.

Att skriva anmälan om detta stort upplagda verk redan 1964 är en svår uppgift. Det är rent arbetsmässigt ett mödosamt arbete att följa Thaning i spåren, särskilt om man samtidigt vill läsa parallellt i Grundtvig. Liksom fallet är med all annan forskning, kan dess värde slutligen bedömas först i forskningshistoriens ljus. Det är emellertid att antaga, att värdet kommer att bestå $i$ vissa och väsentliga avseenden. Det är också att antaga att boken, på grund av de personliga och miljöbestämda förutsättningarna, relativt snabbt kommer att åldras. Det är det pris man får betala för en skildring med liv i.

De första ord man läser i Kaj Thanings nära 8oo sidor stora disputats om Grundtvig är dessa: "... jeg maatte arbeide mig op imod Strømmen baade hos mig selv og andre." Citatet är hämtat från fjärde årgången av Danskeren ( I 85I ), ur avhandlingen "Dansk Oplysning" (Danskeren IV s. 287). Orden står på försättsbladet såsom motto för hela verket "Menneske først - Grundtvigs opgør med sig selv I-III", I963 (Skrifter udgivet af Grundtvig-Selskabet XIII). Citatet är välfunnet, uttrycker kort författarens syn på Grundtvigs person och litterära produktion. "Grundtvigs opgør med sig selv" är ju enligt Thaning huvudtemat såväl i Grundtvigs liv som hans författarskap. Naturligt nog blir det därför huvudtema och metodisk riktpunkt för boken om Grundtvig. Arbetets huvudtes ansluter sig också väl till mottots ordalydelse: årtalet ${ }^{8} 8_{32}$ betyder en omvändelse till människolivet, en omvändelse som för alltid skiljer mänskligt och kristet åt.

Läser man emellertid vidare i Grundtvig-texten, finner man att sammanhanget $i$ texten direkt strider mot huvudtesen $i$ "Menneske først -". Grundtvigs text är rik på synpunkter. Den är riktad mot ensidig själs- och förnuftsdyrkan hos "tyskarna", under hävdande av det verkliga livets rätt. Medan han hävdar att tyskarna opererar med en klyvning av människan, varigenom det andliga kommer att stå i motsättning till det kroppsliga, argumenterar Grundtvig positivt utifrån en helhetsbetraktelse av människan. Såsom ofta avgränsas det mänskliga gentemot det djuriska och det djävulska. Frågan om det mänskliga och det kristna tas flerstädes upp. I direkt anslutning till Thanings motto heter det:

"Siden imidlertid det christelige Lys, der bærer sig ad med os alle, som alle kicerlige Forældre skulde bære sig ad med Menneske-Børn, 
nu i hele tusind Aar har skinnet over Danmark og aabenbar særdeles forlystet det danske Øie og klaret mange Rynker fra utallige Dannemænds og Dannekvinders Pande, saa slutter jeg, at det danske Hjerte maa have en meget dyb og inderlig Følelse af, at den christelige Oplysnings-Maade er den rette menneskelige, og da den dog saa almindelig forsømmes, ja bestrides i Verden, ventelig ogsaa være den guddommelige, saa at, naar Dannemænd og Dannekvinder blot turde for Tyskerne, og især for Hjemtyskerne, som de ikke godt kan holde tre Skridt fra Livet, da vilde de baade ganske anderledes godt end hidtil benytte sig af den christelige Oplysning, og, det bedste, de kunde, efterligne den $\mathrm{i}$ hele deres indbyrdes Underviisning, BørneOpdragelse og Skole-Indretning." A. a. s. $287 \mathrm{f}$.

Denna textmassa, pedagogiskt så intressant, redovisas inte när texten åter tas upp s. 633 ff (vid genomgången av "Dansk Oplysning"). Den går starkt emot Thanings grundtes. Thaning säger att Grundtvig i dessa avhandlingar "går nærmere ind på det særlige ved dansk tænkemåde og drager grænselinier - nu ikke $\mathrm{i}$ forholdet til kristendommen, men til fremmed filosofi"' (s. 633). Karakteristiken är inte korrekt, inte heller uttömmande, men den är utmärkande för Thanings textanalys. Han söker efter en tankegång, som skall vara den röda tråden i Grundtvigs "selvopgør", och när han funnit den, får övriga inslag i väven ligga eller bagatelliseras. Den metodiska grundprincip, Thaning gjort till sin, rättfärdigar ett sådant tillvägagångssätt. I angivna texter återkommer i själva verket problemet mänskligt-kristet åter och åter. Ett konstitutivt element i "Dansk Oplysning" är därjämte den filosofi han själv utgår ifrån, uppbyggd kring modsigelsens grundsætning, "Grundloven for al sand Oplysning" (Danskeren IV s. 348). Det är omöjligt att ge en historiskt riktig skildring av Grundtvigs syn på det mänskliga, om man bagatelliserar detta inslag i hans tanke- och idévärld. Detsamma gäller för förståelsen av hans kristendomstolkning: Grundtvigs lagbegrepp får sin karaktär genom hans filosofi. En historiskt riktig beskrivning av Grundtvig måste göra allvar av detta för vår tid främmande sätt att argumentera, annars blir beskrivningen inte korrekt. Thaning bagatelliserar detta element, "... hans fremførelse af den virker kun som en reminiscens fra hans apologetiske dage ..." heter det s. 634. Thaning litar, i enlighet med sin metod, mera på sitt subjektiva intryck av texten än på vad som faktiskt står där. Grundtvig betecknar själv modsigelsens grundsætning som »den Vei, hvorpaa jeg er kommet til 
min danske Oplysning” (Danskeren IV s. 347). Hans sätt att använda sig av detta argument $\mathrm{i}$ den dåtida debatten förändrades förvisso under hans levnads lopp, men det förblev förvisso också en grundförutsättning för själva hans sätt att tänka och känna. - Ovanstående anmärkningar vid själva starten får stå bara som exempel på de överraskningar man kan finna när man går från Thaning till Grundtvig. Jag skal redovisa ytterligare av samma slag längre fram.

Man kan naturligtvis när det gäller spänningsförhållanden mellan en tes $\mathrm{i}$ ett idéhistoriskt arbete, som avser att påvisa en bestämd struktur eller dynamik, och det rikhaltiga och kanske brokiga materialet påstå att det just är spänningen mellan tes och material som gör framställningen intressant. Redovisning av material enbart, fastän också det ofta kräver en mödosam forskningsinsats, är bara en etapp på vägen mot ett förstående. Först $\mathbf{i}$ brytningen mellan material och interpretation får det behandlade gestalt och karaktär för oss. Den som vill förstå kan inte undvara hypoteser under sina försök att fatta innebörden i ett material, han för kanske preliminärt ut vad han sett $\mathrm{i}$ tesens form och när undersökningsarbetet fått slutgiltig form, presenteras alltsammans såsom en teori. Den som vill förstå undgår inte teorien. - Den som vill förstå vetenskapligt måste emellertid göra klart för sig hur han förstår och vad materialet tilllåter eller inte tillåter. I denna spänning mellan teorien och materialet sker den vetenskapliga bearbetningen. Grundläggande är därvidlag att teorien (tesen) skall justeras efter materialet, inte tvärtom. Blir det för mycket material över, som inte passar in i det invarianssystem man kanske vill påvisa, får man antaga, att tesen är felaktig på just detta material. Man har då möjligheten att justera tesen, med risk att den blir intetsägande, eller att inskränka dess giltighetsområde.

En viktig form av självbesinning är det också att göra alldeles klart för sig (och läsarna) hur man uppfattar arbetsuppgiften, vad man söker uppnå med sin framställning och med vilka metodiska grepp det sker. Metoden är ett värn mot subjektivism, skall försvåra för författaren att förbise relevanta förhållanden. Thaning har tillämpat en metod, varigenom han gjort det lätt för sig. Målsättningen är att beskriva den "virkelige". Det betyder att han söker sig bakom dokumenten till personen, som förutsättes ha ett problem, vilket ständigt bearbetas. Endast i denna process framträder den verklige Grundtvig. Dokumenten sorteras och värderas så utifrån detta "opgør". Ambitionen att finna den "verklige" kombineras därtill med en an- 


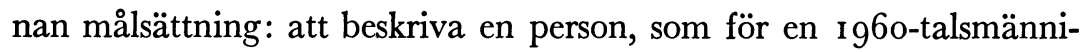
ska kan te sig "levande". - Det säger sig självt att dessa två målsättningar är svåra att förena. Den senare, sökandet efter "den levande Grundtvig", som har något att säga oss idag, medför att element i Grundtvigs värld som framstår såsom antikverade eller som är ideologiskt och teologiskt inopportuna sorteras ut. Försöket att nå utöver dokumenten och att t. o. m. i strid mot dessa rekonstruera en historisk person, så att hans inre jag blottas, måste betecknas som överambitiöst och är naturligtvis faktiskt ett omöjligt företag. Om detta måste betecknas som överambitiöst, i det man därvid vägrar acceptera att det vetenskapliga förståendet har sina gränser, måste å andra sidan moderniseringen betecknas som lättvindligt handhavande av historiskt material. (Om metoden se tills vidare förordet samt s. I3 ff och s. I04).

Genom sin tes, sättet att genomföra den och det därur härledda forskningsprogrammet, har Thaning kommit att intaga en unik position bland Grundtvigforskarna. Trots 12 arbeten i "Skrifter udgivet af Grundtvig-Selskabet" före honom själv och i 6 årgångar "Grundtvig-Studier" samt åtskilliga arbeten, som publicerats på annat sätt, har man i den nyare forskningen kring Grundtvig inte lyckats ge en riktig bild av honom, menar Thaning. Man har nämligen huvudsakligen sysslat med den tidigare Grundtvig och inte haft förståelse för att Grundtvig omvänder sig, i femtioårsåldern. "Det er derfor trods megen flid ikke et billede af den virkelige Grundtvig og hans problem, man er nået frem til"', heter det s. I4. - En sådan hållning ställer stora anspråk på inläsning i och vederläggning av andra forskares verk och problemställningar. Trots den utmanande attityden finner vi att Thaning endast sporadiskt går in på och citerar de andra forskare som behandlat perioderna före $183^{2}$. Det hade varit av värde om Thaning i ett inledningskapitel redogjort för forskningsläget. Vi hade då fått bevis för att han verkligen på ett seriöst sätt sökt sätta sig in $\mathrm{i}$ andra forskares problemställningar. $\mathrm{Nu}$ heter det $\mathrm{i}$ stället: "Når jeg imidlertid uden nærmere stillingtagen til de forskningsresultater, man er nået til vedrørende den tidlige og uafklarede Grundtvig, vover at opridse det problem Grundtvig i 1832 får lys over, skyldes det tilbageslutning fra problemets løsning!" (s. 14). - Thaning läser "baglæns" från 1832. Det betyder att tesen om detta årtal får bestämma tolkningen också av Grundtvigs liv och författarskap från den tidigaste barndomen fram till femtioårsåldern. Författaren 
betecknar t. o. m. detta tillvägagångssätt som det enda möjliga: "Hvad hans barndom her (dvs. i kampen för livsproblemets lösning) har betydet for ham, bliver kun klart netop gennem tilbageslutning fra problemets lösning." (s. I 4-15). Detta "kun" gör undersökningar, som utgår från andra förutsättningar, tämligen värdelösa. Det är i sanning överraskande att $i$ en akademisk avhandling möta ett metodiskt resonemang av detta slag. I stället för att taga på sig bevisbördan för att såväl problemställning som problemlösning är riktiga, utgår han från det som skall bevisas. Årtalet ${ }_{1} 8_{32}$ påstås alltså i detta verk vara avgörande, inte endast för tiden efter - men också för tiden före 1832 ! Följden av att 1832 är interpretationsprincip hela vägen fram blir att det, som inte pekar däremot försvagas. Ett exempel härpå är att "Kirkens Gienmæle" inte spelar någon roll i kapitlet "Grundtvigs problem", som innehåller en framställning av hans utveckling fram till 1832 . Författaren har haft på känn att det kan riktas en invändning här. Hans motivering för att "Kirkens Gienmæle" ej får plats i sammanhanget är dubbel (s. I 04, not I 2). När det gäller att följa "udviklingen og afklaringen" blir annat material viktigare, heter det, t. ex. Søndags-Bogen III. - "Udvikling og afklaring" betyder naturligtvis utveckling mot 1832 . Här ser man klart vad tesen om $183_{2}$ betyder för Thanings textbehandling och texturval. En hel skrift försvinner ur sammanhanget! Tesen är den ena motiveringen härför, den andra är att de tankeelement som hör samman med "opdagelsen af i 825" av Thaning personligen värderas negativt: vi möter här en inre svaghet i Grundtvigs kyrkosyn. Denna personliga värdering är tillräcklig grund för att materialet bortsorteras. Thaning intar $\mathrm{f}$. ö. samma hållning till ett annat huvudverk, "Den Christelige Børne-Lærdom". I värderingen av detta heter det: "Dødvægten i "Den Kr. Bl." er opdagelsen af I825 og de lange udredninger, den medfører. Det levende i bogen er indslaget fra $183^{2}$. Grundtvigs teologi vil i det følgende blive belyst fra denne kant." (s. $\left.65^{8}\right)$.

Av största intresse blir det att se vad för instrument som användes för att beskriva den negativa sidan av "opgøret". Vid beskrivningen av en omvändelse blir naturligtvis det, någon vänder sig från, av stor vikt. Det instrument Thaning framförallt använder för att teckna den negativa bakgrunden till omvändelsen är "bodskristendommen", varierat med uttrycken "fastekristendom", "pilgrimssyn", "gnosticisme" ("den lutherske bodskristendoms, ja, ortodoksiens gnosticisme", s. 6o), 
allt detta som beteckning på barndomens religiösa miljö. 'Den lutherske bodskristendom, der prægede præstehjemmet $\mathrm{i}$ Udby, har sat dybe mærker i barnesindet, og det er netop dette barndomsindtryk, som han først i i $832-48$ år gammel - når frem til at tage stilling til", s. I5. - Jag har själv tidigare påpekat att Gr:s fastepredikningar t. ex. visar, att han vänder sig mot seden att sörja och göra bot och i stället visar framåt mot uppståndelsen och segern i Kristus. Det är alldeles klart och nästan banalt att påpeka. Gr:s teologi får sin färg just av segermotivet. Det är emellertid en sak att konstatera detta, och det bör konstateras. En annan sak är att använda något som instrument i sin tolkning. Thaning bygger ut denna sida hos Gr. med hjälp av de citerade uttrycken och liknande. "Bodskristendommen" skall vara en historisk storhet, emanerande från hemmet, men är ytterst stereotypt skildrad. "Den lutherske pilgrimskristendom må ifølge sit væsen advare - selv mod Skaberens eget værk", s. 72. Med dylika grepp får man en karikerad bild av hans utveckling. Här kräves en rent historisk påvisning för att man skall acceptera resultatet.

Redan tidigare har Thaning tagit upp barndomsmiljöns religiositet. I "Højskolen til debat" heter det, s. 8o: "Da han var lille og sad og læste $\mathbf{i}$ faderens tykke bøger, kom faderen en gang imellem ind $i$ stuen, lod sig læsningen fortælle, retted alt med kristendom. Ingen dansk har som Grundtvig forsøgt at rette alt med kristendom, men nu opgav han det". - Benägenheten att karikera framträder här. Citatet "lod sig læsningen fortælle, retted alt med kristendom" är från "Kvædlinger eller Smaakvad" I8 5 och dikten "Til Cathrine Marie Bang ...". Slår man emellertid upp och själv läser dikten, finner man, att det står "retted den", alltså läsningen, det står inte "retted alt". Men Thaning vill gärna ha det till at såväl fadern som sonen rättat allt med kristendom. Vi står här vid en viktig punkt $i$ Thanings dokumentation, därför bör saken påpekas.

Den fråga som gång på gång inställer sig är denna: när årtalet I832 och "opgøret" är riktpunkt på ett sådant sätt att det som inte pekar dit måste få mindre betydelse eller utsorteras (Thaning anser "bisætningerne" vara viktigare än huvudsatserna, om de pekar mot I 832), vad blir då det yttersta kriteriet för tolkningen? Totalsammanhanget $\mathrm{i}$ åskådningen kan inte tillmätas betydelse. Det sammanhang Gr. själv ser i sitt eget liv och där han ofta betonar kontinuiteten, kan inte heller vara avgörande. Det strider ju mot tesen. Kvar står att Thaning ständigt måste söka sig fram mot Gr:s "selvopgør" och 
omvändelse, som inte föreligger som en given storhet, men som spåras i texterna. Thaning har också i debatten efter disputatsens framkomst förklarat: "At der er tale om en omvendelse til Guds skaberværk i 1832, kan hverken bevises eller modbevises" (Kristel. Dagbl. I8/2 I 964). Att diskutera en framställning som har en sådan karaktär är inte lätt! Det blir ytterst en fråga om sannolikhet.

Det språk som Thaning måste använda för att beskriva Gr. vittnar om dessa verifikationssvårigheter. Thaning måste åter och åter hänvisa till det omedvetna (s. I5), det medvetna sättes upp mot "virkeligheden" (s. 35), Gr. "har ikke fundet sig selv" (s. 43 f.). Thaning talar om "det skjulte angreb på pilgrimskristendommen, som Grundtvig - uden at forstå rækkevidden af det - ikke kan undgå at føle knyttet til de Englandsindtryk, der sejrer i hans tankeverden året efter" (s. 69). På s. ı 04, not. I I förklaras en svag polemik mot "Verdens Vise" med hjälp av "en skjult indflydelse fra Englandsindtrykket". På s. 6 19 är frågan den, om Gr. i en text avser I824 eller I832: "... den nærmere udformning af tankegangen viser, at I 832 er skellet, hvad Gr. måske er klar over". S. 350: "Skjult i disse ord mærkes det selvopgør - .." - Exemplen torde vara tillräckliga för att visa vilka problem det är med verifikationen. Thaning säger också själv ytterligare i citerade artikel: "'Omvendelsen" kan ikke verificeres "videnskabeligt" ".

Denna programmatiskt subjektiva hållning till det historiska stoffet, Thaning medger ju öppet att hans tolkning är personligt bestämd, hindrar honom inte att som disputatsens slutkapitel foga en onyanserad kritik av undertecknads systematiska undersökning "Mänskligt och kristet. En studie i Grundtvigs teologi", I96o. Ett avgörande inslag i denna kritik, som jag återkommer till, är att Thaning ogillar den teologiska begreppsapparat jag använder och som är framgången ur en immanent förståelse av Grundtvig, så som hans författarskap faktiskt föreligger i tryckt form. - Uppenbart är att det är omöjligt att förstå Grundtvigs kristendomstolkning utifrån Thanings helt villkorliga källsortering. Det problem, som jag tagit upp i min bok, och vars behandling Thaning så häftigt angriper, är utifrån hans arbetssätt icke lösbart. Däremot är det klart att våra böcker utifrån själva målsättningen måste te sig helt olika, Thaning behandlar Grundtvig konsekvent utifrån sin "kant", medan jag själv bemödar mig om en immanent sak- och problemframställning. Eftersom hela Thanings verk mynnar ut i en 30 sidor stor uppgörelse med 
min Grundtvigtolkning (Kapitel I6, To Grundtvigopfattelser, s. $745 \mathrm{ff}$ ), kommer jag här i den utsträckning det av utrymmesskäl är möjligt att pröva hållbarheten av hans kritik och de förutsättningar den vilar på. Tills vidare kan fastslås att Thanings materialval och textanalys bestämmes av två, sinsemellan sammanhängande förutsättningar: tesen om 1832 och hänsynen till vad som är levande och förståeligt för eftervärlden. Bägge synpunkterna, som fungerar såsom metodiska riktlinjer, kan återföras till uppfattningen att Grundtvigs "problem var grundmenneskeligt og må opstå overalt, hvor kristendommen når hen." (Förordet). I detta postulat ligger avhistoriseringen på lur. Det gäller att förstå Grundtvigs inre kamp, i dess allmängiltighet och detta t. o. m. bättre än han förstod sig själv (förordet: "Først drejer det sig dog om selv at komme til at forstå ham. Man kan da godt blive vildledt af det, han selv så som sine store opdagelser. En tolkning af ham kan derfor komme i modstrid med hans egen opfattelse af, hvad han især havde at sige. Det kan jo imidlertid blive de levendes opgave at søge at forstå de døde bedre, end de forstod sig selv").

I och för sig är det inte orimligt att eftervärlden förstår en historisk person bättre än han förstod sig själv. Men i Thanings sammanhang har uttalandet en speciell innebörd: när Thaning deklarerar att han inte kommer att taga hänsyn till Grundtvigs självbiografiska uttalanden (om de inte stöder honom själv, får man tillägga, se t. ex. s. 27 I), utrymmer han den sista skansen i sitt metodiska försvarsverk. Han behöver inte längre stå för någonting, allt slutar i en subjektivism som benämnes "grundmenneskelig", med starkt deterministisk färgning. Thaning berättar i den mycket citerade artikeln "Et tredie Grundtvigstandpunkt" (i Tidehverv I94I, ursprungligen föredrag i Studenterkredsen, Köpenhamn) att Grundtvig för hans studentgeneration framstod såsom dold bakom sitt stora skägg. Men några stycken anade att därbakom fanns en människa och aningen blev till visshet. Thaning proklamerade här för första gången sin tes i någorlunda tydlig form: det måste finnas en annan Grundtvig (än Nørgaards och Poul Engbergs)! Länge har Thaning ryckt i Den Gamles skägg, nu är det plötsligt borta och vi ser ett ansikte som är påfallande likt författarens eget!

Det är i frågan om Thanings Grundtvigtolkning, som bygger på alldeles bestämda subjektiva, personliga förutsättningar hos författaren och tillika förutsätter en liknande hållning hos läsaren, nödvän- 
digt att taga hänsyn till de personliga utgångspunkterna på ett sätt som annars inte brukar behövas $\mathrm{i}$ akademiska sammanhang. Tesen är framvuxen ur miljöerna kring tidsskrifterna "Dansk Folkeliv" och "Tidehverv", ur 20- och 30-talens inomdanska problematik (se Tidehverv I 94 I :8, spalt 86). Denna problematik var av ideologisk karaktär, rörde kyrkan och de övriga kulturfenomenen, det mänskligt-kulturella i dess samtidighet med det kristna och det religiösa. De inre brytningarna i och mellan dessa miljöer var starka, kritiska personligheter bröt sig ut, sökande efter nya hållpunkter. "Opgøret" blev den karakteristiska hållningen, utmanande, ej sällan drivet till arrogans. "At alt af betydning må fødes under opgør, blev mig selv klart gennem det tidsopgør, der skabte og som har bestemt bladet Tidehverv", säger Thaning i sitt tillbakablickande förord. I sökandet efter nya hållpunkter grep man tag i Grundtvig. - Att skildra denna kampfyllda miljö är att skildra tesens ursprungsmiljö. Den blev till tes just om Grundtvig genom Kaj Thanings existentiella engagemang i denna problematik och i Grundtvig själv, som person och som skribent. A. Pontoppidan Thyssen har (i kronikken "Menneske først - og sidst!"', rec. i Jyllands-Posten 2 I/1 2 I963) påpekat att Thanings Grundtvigtolkning här har sin förhistoria, i kritiken av - "det menneskelige" som en idealistisk forædlet livsform og af det grundtvigske menighedsliv som et særlig åndeligt og kristeligt fællesskab ...”. Thyssen pekar på Knud Hansens roll i sammanhanget, när denne menar att det avgörande för Grundtvig just var att han hade "... fået øje på det virkelige menneskeliv, der betyder bundethed til jorden og solidaritet med tiden og folket". Redan här, i den nya miljö som blev till i kritiken av det gamla, möter man den Thaningska ensidigheten.

Thanings tes, omvändelsen till människolivet $183^{2}$, som i första ögonblicket synes så punktuell, drages ut i båda riktningarna och blir den röda tråd som skall gå genom hela Grundtvigs liv, manifesterad i hans skriverier. Mest förvånande är, att tråden drages bakåt, ibland får man intrycket att $183_{2}$ rentav kan vara orsak till en formulering årtionden tidigare. Det mest intressanta är emellertid att konstatera att den röda tråden brister långt före Grundtvigs död. Enligt Thaning kommer ı 864, på grund av de starka intrycken från kriget, ett nytt motiv, tröstemotivet, in och ger det hela ett eskatologiskt perspektiv (s. 704 ff.). (Detta hindrar inte Thaning att på s. 64 tala om Grundtvigs "endelige livssyn"!). Också andra förklaringsgrunder nämnes, 
när det brister, t. ex. att han är eller just varit sinnessjuk, eller helt enkelt: "Han er gammel".

Thaning har byggt upp sin Grundtvigtolkning på ett sådant sätt att det inte är möjligt att ge en framställning av Grundtvigs totala teologiska åskådning. Detta dels genom själva frågeställningarna, dels på grund av bortfallet av väsentliga teologiska texter (såsom Kirkens Gienmæle och stora delar av Den christel. Börnelærdom). En av de intressantaste frågorna inför denna tolkning av "den hele Grundtvig" utifrån en enda punkt, året I 832, är när tesen blir helt omöjlig att upprätthålla. Det inträffar långt före i 864 . Jag skall senare peka på texter från I840- och I850-talen, som är omöjliga att tolka med Thanings tes (vilket han själv visar). Det skall också anföras texter, som visar att tesen är överflödig. Man undrar, när det nu förhåller sig så, varför tesen om 1832 överhuvudtaget skall dragas genom hela författarskapet.

Förklaringen torde vara att det blivit något av en hederssak att utförligt dokumentera en tes, som formulerats utifrån aningar om ett visst sammanhang och i skarp polemik mot andra uppfattningar. Det ligger över tjugo års arbete mellan tesens första formulering och dokumentationen. Tesen skall alltså vara densamma, medan materialet tillväxer oavbrutet; till det tryckta lägges otryckta förlagor och utkast. Arbetet med Registranten över Grundtvigs ej publicerade papper har försiggått under tiden för Thanings disputatsskrivande. Han har tagit verksam del däri. Man måste beundra Thanings mödosamma arbete med det opublicerade, det bör få sin rätta värdering. Men det var utan tvivel olyckligt att tesen föddes för tidigt, av solidaritet med tesen har Thaning drivits till en skev framställning. Det nödtvungna genomförandet av tesen har också medfört att verkets karaktär blivit ytterst oklar. I vilken genre hör boken egentligen hemma? Är den vetenskap eller uppbyggelse eller bägge delarna? Är den biografisk, allmänt idéhistorisk, kyrkohistorisk, teologisk eller "ideologisk"? - Det rätta svaret är förmodligen att boken är lite av varje eller allt detta. Näst frågan om tesens genesis, är frågan om hur tesen slutligen fattas och genomföres av vital betydelse för att förstå denna Grundtvigtolkning. Det betyder att intresset riktas direkt på hur författaren uppfattat sin arbetsuppgift och hur han genomfört den, dvs. på bokens problemställningar och uppbygnad.

I en rad offentliggöranden från I94I och framåt har betydelsen av Englandsresorna och året 1832 varit huvudsynpunkten för Tha- 
nings Grundtvigtolkning (se t. ex. Tidehverv I941:8-9; I942:2; г943:6; г 944:6; Dansk Udsyn г953:6, ett föredrag om "Grundtvig og den danske Folkehøjskole", äv. i samlingsboken Højskolen til debat I96I; "Grundtvig og Kold" i samma bok, tid. tryckt I957; Grundtvig-Studier 1953, Grundtvigs Møde med Ireneus.). Englandsresornas betydelse har tidigare påpekats av många, det är allmängods. För Thaning blir emellertid Englandsresan I83o och dess genomslag 1832 den enda vägen att förstå Grundtvig. Alla som arbetat med Grundtvig under de senaste årtiondena har väl brottats med Thaning. Personligen har jag ägnat stor möda att förstå innebörden i Thanings tolkning, genom att läsa hans skrifter och genom personliga samtal. På ett tidigt stadium av mitt arbete hade Thaning vänligheten att möta upp i Lund till diskussion. Jag var även i Asperup. Däremot hade ingen av oss tillfälle att möta upp till den andres disputation.

Under dessa konfrontationer fick jag aldrig något annat intryck än att Thanings undersökningar skulle föra fram till en principiell framställning av systematisk-teologisk art, med stark tonvikt på Grundtvigs skapelseuppfattning. Något annat kan heller svårligen utläsas av de tidigare publikationerna. På denna punkt, i själva uppgiftsfixeringen, har skett en märklig förskjutning i disputatsen. Från att ha gällt Grundtvigs principiella tolkning av förhållandet mellan skapelse och frälsning har synpunkten alltmera blivit, hur Grundtvig förhåller sig till olika fenomen i kultur och samhälle. Från att ha varit en teologisk ansats, har Thanings arbete blivit alltmer ideologiskt. ${ }^{1}$ ) "Kultursyn" och "kulturkamp" är nya och framträdande begrepp i boken. (Jfr. hur argumenteringen i polemiken mot min bok vrides över till att avse "kulturkampen" s. 749). - Parallellt härmed har metoden alltmer subjektiverats. Grundtvigs uppträdande som kulturarbetare framstår som en direkt konsekvens av omvändelsen. I så måtto är förskjutningen i sättet att bearbeta uppgiften förståelig, ett uttryck för Grundtvigs ändrade intresseinrikning. Men här gäller det att klart se vad man talar om och inte sammanblanda Grundtvigs accepterande av en pluralistisk kultur med hans personliga åskådning. När Grundtvig skulle göra klart vad "Englandsindtrykket" inneburit i Mands Minde exempelvis, gör han det i formuleringar som

1) Termen »ideologi« användes här $\mathrm{i}$ den mening den vanligen har i modern socialfilosofi och »political science $\ll$ : livssyn i relation till kultur- och samhällsproblem. 
svarar mot vad vi kallar kulturell pluralism. En dylik hållning är ett sätt att komma till rätta med faktiskt föreliggande olikheter och motsägelser i en kulturkrets. Det är ett ställningsstagande av praktisk art, man kan inte utan vidare överföra ställningstagande i en given kulturpolitisk situation till att gälla en persons faktiska åskådning. Att en person hyllar och går in för en pluralistisk kultur, innebär inte utan vidare utsuddning av den egna åskådningen. Innebörden i kulturell och politisk pluralism är ju tvärtom att olika åskådningar oavkortade existerar och fungerar samtidigt $i$ ett samhälle.

När man nu som Thaning ensidigt beskriver Grundtvig utifrån denna "kant", en beskrivning som i materialurvalet och temavalet är tendensiös, riskerar man att världsöppenheten blir starkt överdriven. Här lurar en felfaktor, understödd av grundtesen om att det gäller att förstå det inre hos Grundtvig och grundsatsen om att det är "det levande" hos honom som skall skildras. Med denna metod kan man å ena sidan aldrig ge en historiskt riktig beskrivning av Grundtvigs samhälls- och kultursyn. Därtill krävs andra instrument, framförallt måste man därvid ut ur Grundtvigs inre liv till de faktiskt föreliggande historiska förhållandena. Å andra sidan är det omöjligt att ge en immanent beskrivning av Grundtvigs kyrkosyn, dvs. så som den oavkortat framstår $\mathrm{i}$ hans författarskap. Thanings framställning får med inre nödvändighet en oklart ideologisk karaktär.

Användingen av uttrycket "sekularisering" är härvidlag belysande. "Det er berettiget at kalde Grundtvig en af de danske fædre til den såkaldte sekularisering, og det refererede sted viser, at han er sig bevidst at være det", heter det anakronistiskt på s. 682. - Innebörden i begreppet "sekularisering" är ju ursprungligen att det borgerliga livet frigöres från sin dominans av kyrkliga institutioner och religiösa föreställningar. I denna mening är uttrycket användbart, t. ex. för att beskriva förändringen i Grundtvigs kyrkopolitiska uppfattning I 825 och tio år senare. Uttrycket är då inställt i ett samhällshistoriskt sammanhang. Hos Thaning fyller emellertid termen "sekularisering" en dubbel funktion. Förutom funktionen att uttrycka Grundtvigs syn på förhållandet mellan kyrka och kultur, har termen en starkt teologisk värdebetoning. Sekulariseringen bejakas av Thaning och här är det som oartikulerade inflytanden från samtida kontinental teologi kommer in. I Tyskland har det t. ex. av Friedrich Gogarten hävdats att sekulariseringen står i samklang med ett rätt Gudsförhållande och därför bör bejakas av en kristen. Den är, enligt Gogar- 
ten, ytterst en konsekvens av evangeliet, innebärande att "världen" avklädes sin ideologiska iklädning. Gängse tankegångar av detta slag i tysk teologi löper genom "Menneske først", dock utan att det närmare angetts, varifrån de härstammar. På vissa ställen, som det citerade, går dessa tankar i dagen (s. 682, 784; se f. ö.s. ı o8). - Viktigare är dock att de bestämmer tolkningen i dess helhet. Värderingen av Grundtvigs insats, i sin tur genom principen om "det levende" Thanings metodiska utgångspunkt, sker utifrån denna sekulariseringsteologi (tydligt artikulerat även i uppsatsen Grundtvig og Kold i Højskolen til debat s. 82, 92 f, 96; beträffande de kanaler, genom vilka dessa tankar strömmat in i Danmark, kan anföras Thanings till den tyske teologen Götz Harbsmeier riktade ord vid disputationen, att "tysk teologi har kunnet udfordre os og ruske op i vor tit sløve og frygtsomme holdning til spørgsmaalene", bekräftat av Thaning i Aarhus Stiftstidende 4 jan. I964). För att kunna förstå Thanings Grundtvigtolkning måste man ha dessa teologiska tankelinjer eller snarare teologiska tendenser, klara för sig. Verket "Menneske først -" framträder i det yttre inte som teologiskt, inte heller är det kyrkohistoriskt (jfr. s. I04). Däremot är Thanings disputats i hög grad kryptoteologisk. Hans motvilja mot att arbeta med frågor och svar ur den klassiska dogmatiken är uppenbar (jfr. s. 748), i stället väljer han såsom slagruta "den såkaldte "sekularisering" ". Sekulariseringen framstår som en god frukt av "omvändelsen".

Såsom Thaning $\mathrm{i}$ sin tolkning ständigt gör rekurs till $183^{2}$ och omvändelsen, så kommer man ideligen dit vid en värdering av hans verk. Det är verkligen den springande punkten. Primärt har tesen psykologisk innebörd, Gr. omvänder sig til människolivet och framstår därmed för eftervärlden som en av fäderna till sekulariseringen i Danmark. Sekundärt betyder inkorporerandet av sytematiskt-teologiskt tankegods, den så kallade "sekulariseringen", emellertid också en annan sak: här kommer in en faktor som bestämmer tolkningen av Gr:s teologi och idévärld överhuvudtaget. För totalbedömningen av Gr. blir denna tankeriktning faktiskt av primär betydelse, fastän den inte framträder öppet, utan snarare kan sägas strömma in genom en bakdörr. Under tesen om "skiljandet" ligger kryptiskt en teologisk enhetsuppfattning, förutsättningen att sant mänskligt och kristet kan återföras på en gemensam bas genom skapelsen. Användningen av citatet från Børnelærdommen på s. 682 är därvidlag belysande: "Kristi Tro kunde nemlig ikke være Sandhedstroen om det grund- 
virkelige Forhold mellem Sandhed og Løgn, Lys og Mørke, Liv og Død, eller mellem Gud og Verden, Gud og Menneske, Aand og Kjød og Tid og Evighed, dersom ikke Troens Aand, som SandhedsAanden, i Tidens Løb udviklede og klarede den menneskelige Oplysning om alle disse Grundforhold". Detta citat, som så tydligt markerar enheten i Gr:s åskådning, kan Thaning anföra i omedelbar anslutning till att sekulariseringsbegreppet införts. I citatet ligger klart en förutförståelse av det "grundvirkelige", utifrån vilken det mänskligas frihet och mångfald också klart och starkt kan hävdas. Det är $\mathrm{i}$ texten fråga om en principiell samsyn av mänskligt och kristet, med stora öppningar för det mänskliga, sammanhang och öppningar som klart kommer till synes vid en filosofiskt-teologisk analys av begreppen "Sandhed og Løgn", "Liv og Død", "Gud og Menneske", "Sandheds-Aanden", dvs. de filosofiskt-teologiska grundförhållanden, som också är grundmotiv i Grundtvigs idévärld. Thaning företar ingen sådan principiell analys, men han kan inte undvika att texterna åter och åter tränger sig fram (detta trots utsortering av särskilt besvärande källor). Sammanhangen artikuleras inte av författaren, som i stället för in den dunkelt presenterade sekulariseringsteologien. Denna hade f. ö. blivit mera nyanserad om Thaning vid sidan om 'Säkularisierung" öppet hade arbetat med det parallella, negativt färgade begreppet "Säkularismus". Det är typiskt för Thanings skrivsätt att detta saknas, men likväl dock kryptiskt föreligger i den antiideologiska och antisystematiska tendensen. Som ändå likafullt har en klar ideologisk och systematiskt-teologisk tendens!

Det är både teologi och förkunnelse inbyggd i "Menneske først -", boken beskriver och föreskriver såväl omvändelse som en viss hållning till världen. Thaning har haft såväl ett personligt som ett kulturpolitiskt ärende. I klartexten är det Grundtvig, det handlar om, och det mänskligt-kulturella det gäller, i verkligheten är det ett spel om envar. Den efterföljande debatten i anledning av boken har ytterligare klarlagt detta. I den ovan citerade kronikken "Opbyggelsesbog eller videnskab - eller begge dele?", Kristeligt Dagblad 18/2 1964, ett inlägg med anledning av tidningens referat av debatten om Grundtvigtolkning mellan Thaning och undertecknad i Teologisk forening i Köpenhamn $4 / 2$, klargör Thaning sina intentioner med boken och ger f. ö. upplysande kommentarer till metodfrågan. Där heter det: "Min bog er skrevet til "opbyggelse", til selvopgør og omvendelse for både mig selv og andre - men det er Grundtvigs forfatterskab alene, 
der er dens emne". Thanings Grundtvigtolkning präglas av denna dubbla målsättning, där uppbyggelse- och omvändelsemotivet brukas gentemot läsaren så ivrigt att den historiske Grundtvig kommer i skymundan. Läsaren är en viktig faktor, liksom författaren, Grundtvig är det naturligtvis också. Men han borde ha fått ensamrätt på detta hans eget fält, även om det blivit mindre uppbyggligt på det sättet.

Nyckelordet i Thanings egentliga Grundtvigtolkning är omvändelse - först till Gud, och sedan till människolivet! Denna formulering synes kanske som en överraskande omvändning av hele problemläget. Men denna omvändning ligger in nuce i innebörden av Gr:s egen omvändelse $183^{2}$, liksom den ligger in nuce $\mathrm{i}$ den kontinentala teologi som är förutsätting för resonemanget totalt sett. "Menneske først" slår lätt över i sin motsats "Kristen først" (se s. 61 3 ), därför att Thaning inte kallt analyserat den teologiska problematiken utan i stället ensidigt sett allt utifrån "omvändelsen". Utifrån I 832, som personligt-psykologiskt datum, blir ordföljden just "kristen först och så människa”. Så kan Thaning säga att Gr:s skoltankar "i en vis Forstand" har hans kristna tro till förutsättning (Grundtvig og den danske Folkehøjskole, i Højskolen til Debat s. 47). I Kristel. Dagbl. I 8/2 I 964 heter det vidare om betydelsen av "adskillelsen" I 832: "Kristendommen er nu til for menneskelivets skyld - evangelisk forstået. Verden skal nu ikke længere formes kristeligt - efter et guddommeligt mønster ( I 83 I). Synet på den, ligesom også på kirkeinstitutionen, sekulariseres".

Ideologiska och teologiska tankegångar trängas här tätt inpå varandra. Ideologiskt är det naturligtvis riktigt att tala om sekularisering, i betydelsen frigörelse från religiösa institutioner. Det gäller om synen på kyrkoinstitutionen och även i fråga om skolan: skolan är till för detta livet, ej för det eviga livet. Vad som här är intressant är emellertid tillägget efter uttrycket "for menneskelivets skyld", markerat med tankestreck "- evangelisk forstået". Här går den kristna förutförståelsen i dagen, vi står plötsligt i tankeriktningen evangelium - lag. Dylika omkastningar blir möjliga genom att Thaning ur hela komplex av tankar, primärt uppfattade som samhällsfenomen, vill draga principiellt-teologiska slutsatser. Tanken oscillerar mellan kyrkan i betydelsen kyrkoinstitutionen och kyrkan som systematiskt-teologiskt begrepp. Enda möjlighet att komma till klarhet på denna kardinalpunkt är att företaga en teologisk analys av människosynen i dess lagfunk- 
tion. I stället för att göra detta flyr Thaning in i Grundtvigs inre liv och utläser verkningarna därav i det yttre. Men detta parallellt tecknade inre och yttre skeende framstår som en frukt av att Gr. blivit en rätt kristen. Han kan nu tala rent evangeliskt om förhållandet mellan Gud och människa, himmel och jord, och i kyrkan se enheten dem emellan, heter det vidare i nämnda artikel. - Det är uppenbart att Thaning, när han övergår i rent teologiska utsagor, gör kraftiga medgivanden som pekar i riktning mot en enhetlig teologisk tankeskapelse hos Grundtvig. Ja, man kan påstå att dessa utsagor slår över i motsats mot bokens hela uppläggning. Lika onyanserat som det talas om "Menneske først" och om att Gr. I832 på allvar blev "hedning" (s. 23I), likaså onyanserat, men mera kryptiskt, träder formuleringarna av innebörden "Kristen først" fram. I den tyska sammanfattningen betecknas Gr. helt enkelt som "Fürsprecher für die Säkularisierung, die eine Folge des christlichen Glaubens ist".

Utifrån Thanings sporadiska, men tesaktigt och kategoriskt utformade offentliggöranden före disputatsen I $_{9} 6_{3}$ väntade man sig en framställning av de antropologiska förutsättningarna för $\mathrm{Gr}$ :s teologi. Att genomföra en teologisk framställning med bevarande av Thanings tes är emellertid av inre grunder omöjligt, därtill är Ireneuselementet alltför dominant. Att bevara tesen om $18_{32}$ i någon form såsom giltig för hela $\mathrm{Gr}$ :s liv har varit ett huvudintresse. Arbetets uppläggning har därvid undergått en förskjutning: dels har det blivit ideologiskt i stället för teologiskt, dels har tesen alltmer psykologiserats (utan att dock bli biografisk) och metoden blivit alltmer subjektiv. Den innehållsmässiga beskrivningen av Gr:s livshållning, kulturattityd och verksamhet föres ständigt tillbaka till hans "opgør med sig selv". Vi har fått en bred framställning av följderna av Gr:s omvändelse ı $83^{2}$, så som de avtecknar sig i hans kulturpolitiska utspel, inte en beskrivning av förutsättningarna för hans tolkning av det specifikt kristna i förhållande till det allmänmänskliga och det folkliga. Thaning vill alltjämt vidhålla sina tidigare interpretationer (se s. 747), men det finns som redan påpekats skäl att påstå att såväl tes som arbetsmetod har förändrats i avgörande grad, dock ej mer än att själva årtalet står orubbat kvar. Arbetets titel "Menneske først -" understryker starkt ordningsföljden skapelse-frälsning (lag-evangelium), men är missvisande eftersom resonemanget i sin kärna är bestämt av att han blev människa, därför att han blivit kristen. Tankestrecket i titeln skall förmodligen vara en tankeställare för läsaren. Det antyder emel- 
lertid också att den internt teologiska uppgiften inte är löst av Thaning. Det kristna blir inte föremål för systematisk analys, får i stället formen av ett antagande om ett inre "jag". Dette "selv" uppfattas intuitivt och är i inte ringa grad Thanings alter ego.

I normala fall skulle påståendet i den sista satsen, påståendet att en vetenskaplig författare sammanblandar sin person med den sak som undersökes, vara uppseendeväckande och utmanande. Men så kan det inte framstå i detta fallet: Thaning själv hävdar just att en subjektiv metod är den enda möjliga. "Ingen anden metode fører frem", heter det i Kristel. Dagbl. I8/2 I964. Förklaringen ligger i själva uppgiftsfixerandet: "det er et levende menneske, der skal forstås". Att denna förståelse kan uppnås endast via textanalys och hänsynstagande till historiska förhållanden är klart. Texterna talar emellertid föga om en omvändelse I 832. Inför denna texternas tystnad (det gäller i påfallande grad också Gr:s självbiografiska tillbakablickar) måste man då söka sig in bakom de skrivna orden till personen, som skrev. Mötet med texten blir till ett personligt möte med skribenten, när han skriver. Vi har därmed förflyttats från tempus perfektum, historikerns kategori, till presens. Så har Gr. gjorts samtidig av Thaning, som inte kan acceptera begränsningen $\mathrm{i}$ ett historiskt material och i våra möjligheter till vetande om en person, död sedan nära ett sekel. Att observera är, att denna subjektiva metod inte framstår som en av flera möjligheter. Det är den enda möjliga. En "verklig" Grundtvigtolkning kräver "at man personlig vover et møde med manden", heter det i citerade artikel. Thaning avvisar att man behandlar Gr. såsom ett "material" (Menneske først - s. 748). Den immanenta textanalysen ersättes av eller i varje fall vägledes av en personlig upplevelse. Inlevelse i Gr:s inre liv är det oavvisliga kravet för att förstå honom. - Detta krav på kongenialitet förflyttar kriterierna på tolkningen alltmera över $\mathrm{i}$ tolkarens eget subjekt. Denna överflyttning är naturligtvis betingad av att tesen i så ringa omfattning är avläsbar direkt i materialet. Materialets motspänstighet har medfört att tesen blivit esoterisk, metoden subjektiverats och problemställningarna ideologiserats i långt högre grad än som synbarligen förutsetts. Det har alltmer blivit en fråga om Gr:s omvändelse och dess följder, upplevda existentiellt av Thaning och hans läsare. Verifikationen ligger till sist $\mathrm{i}$ det personliga mötet mellan $\mathrm{Gr}$. och en människa som förstår innebörden $\mathrm{i}$ en omvändelse. Thaning medger att hans disputats "kræver ganske bestemte subjektive, personlige forud- 
sætninger, hvis dens tese virkelig skal kunne "verificeres" (cit. art.) - förutsättningar både hos författaren och läsaren.

Vi står härmed vid huvudproblemet med Thanings disputats, frågan om tesen överhuvudtaget kan verifieras. När det gäller arbeten med vetenskapliga anspråk kan det inte sällan vara svårt att avgöra om de framförda påståendena på ett tillräckligt och godtagbart sätt har belagts. Det är inte sällan diskutabelt. - Ett absolut krav är emellertid att en framförd tes skall vara verifierbar. Det betyder att man måste ställa problemet på ett sådant sätt att det principiellt kan lösas.

Genom sin ambition att rekonstruera Gr:s "selvopgør", även i strid mot föreliggande textvittnesbörd och hans egen självförståelse, har Thaning förlorat fotfästet $\mathrm{i}$ det historiskt givna. Metodiskt sett är det en konstruktion, en konstruktion på smalt fundament: förståelsen av liv och författarskap under ett trekvarts sekel baseras på en enda punkt, 1832. Redan innehållsligt sett är det ytterst osannolikt att detta tillvägagångssätt skall kunna verifieras. Metodiskt är det omöjligt att verifiera en människas innersta kamp med sig själv. Slutsatsen måste bli, att Thaning har påtagit sig en uppgift som icke är vetenskapligt möjlig. Författaren har velat producera sig inom två genrer samtidigt, den vetenskapliga och den uppbyggliga. Verket skall inte bara vara en bok om Grundtvig, den innehåller ett teologiskt "opgør" i allmänhet och framträder som en profilerad kampskrift mot oliktänkande. Detta aktualitetsmotiv förrycker framställningen av den historiske Grundtvig och förringar bokens rent sakliga värde.

Med denna hållning till den historiske Gr. är det naturligt att Thaning blir kritisk mot en tolkning, som syftar till att ge de riktiga proportionerna mellan olika komponenter. Hänsyn till begränsningen i det historiska materialet, såväl kvantitativt som kvalitativt, begränsar möjligheterna att använda historien i dagens strider. Historien tynger, Thaning talar själv om "dødvægt" (s. 658). Har man som syfte att göra upp med nutiden och omvända dagens människa, får man göra sig av med det som tynger. En tolkning av Grundtvig kan komma i motsättning till hans egen uppfattning av sig själv och sitt ärende, menar ju Thaning. Så är också fallet med Grundtvigtolkningen i "Menneske først -". Det är därför inte förvånande att Thaning kommer "i modstrid" mot min bok "Mänskligt och kristet. En studie i Grundtvigs teologi”, I 960 . Förvånande är emellertid den form uppgörelsen med min bok har fått. I en ytterst irriterad stil tillåter sig Thaning förenklingar och uteslutningar som ger en skev bild av min 
Grundtvigtolkning och själva bokens problemställningar. Det är här omöjligt att genomgå alla punkter i detta kapitel (s. 745 ff.), vari Thanings hela framställning mynnar ut. Några nyckelresonemang skall emellertid tas upp. - Av särskilt intresse är s. 746, ty där lägger Thaning - med ett enkelt grepp - grunden för sina resonemang i fortsättningen. Thaning överväger först att i sitt slutkapitel resumera sin egen framställning, men befarar att detta skulle medföra en ofruktbar förenkling av "Grundtvigs" syn. Han vil därför göra "noget andet": han gör en polemisk resumé av min bok. "Sagen er den, at der fornylig er kommet et arbejde om ham, der stemmer overens med mit i synet på, hvad det centrale i sagen går ud på ... Aronsons hovedsynspunkt for behandlingen af emnet er imidlertid det modsatte af mit, så hvis han har ret, har jeg uret - og omvendt." I fortsättningen tecknar sedan Thaning en "motsats" til sin egen framställning.

Här gäller det att göra klart för sig dels vad "det centrale i sagen" betyder, dels vad "det modsatte" betyder. Ur dessa förhållanden skall ju, enligt Thaning, uppstå ett uteslutningsförhållande. Problemställningen hos oss båda skulle tydligen vara densamma, men resultatet "motsatt'. - Jag vill gentemot detta hävda att vi visserligen båda talar om det mänskliga och det kristna, men att vi gör det med så olika problemställningar och så olika metod, att det är oriktigt att påstå att utgångspunkten är densamma. Min bok är "ett försök till karakteristik av Grundtvigs författarskap utifrån systematiskt-teologiska synpunkter (s. 9). Problematiken mänskligt-kristet anges som "den centrala och systematiskt känsliga punkten" (s. I I). Boken har som undertitel "en studie i Grundtvigs teologi". Thanings verk heter "Menneske først -" och handlar om Gr:s "opgør med sig selv". Jag behandlar problemet mänskligt-kristet principiellt såsom ett systematiskt-teologiskt problem. Min problemfixering är från början teologisk. Thaning fick impulsen till sin uppläggning i samband med en undersökning av Gr:s kyrkopolitiska tankar (se förordet). I det färdiga verket är just samhälls- och kultursynen den dominerande aspekten, tolkad "sekulariseringsteologiskt" utifrån Gr:s omvändelse. Min bok är teologisk, Thanings är ideologisk. Endast genom att förbise att det är metod och målsättning som ger en undersökning dess speciella karaktär kan Thaning påstå att våra böcker överensstämmer i uppfattningen av "det centrale i sagen". Våra böcker är i själva verket endast $\mathrm{i}$ viss utsträckning kommensurabla. - Thanings påstående torde 
emellertid väsentligen ha polemisk innebörd. Därmed är nämligen grunden lagd för nästa påstående: att resultatet av våra undersökningar skulle vara motsatt på ett sådant sätt att den ena parten måste ha "rätt", den andra "orätt". - Man frågar sig vad det är för motsatsbegrepp Thaning här arbetar med, som skulle ge denna antingeneller effekt. Uttrycket "det modsatte" återfinner man på s. 6I 3 vid behandlingen av dikten "Menneske først og Christen saa", alltså i samband med Thanings centraltema. Det heter där: "Selv havde han fra I8 Io til I83 I hyldet det modsatte syn: Kristen først og så (derigennem) menneske, selv om han havde forsøgt (sidst i I 823-25) at nå frem til gudskundskaben gennem menneskekundskaben". Jämför även "det omvendte" s. 25 samt resonemanget s. 67 nederst.

Vi står här vid själva axeln kring vilken Thanings teologiskt-ideologiska resonemang rör sig: antingen "Menneske først" eller "Kristen først". Själv står Thaning som bekant för tolkningen "Menneske først" och slutsatsen bör då bli att min "hovedsynspunkt" är "Kristen først", det är ju "det modsatte". Hela resonemanget är naturligtvis orimligt utifrån min bok, men Thaning finner det polemiskt tjänligt. Man kunde lika gärna säga att motsatsen till Gr. före 1832 är $\mathrm{Gr}$. efter I $_{32}$ (nästa steg $\mathrm{i}$ Thanings polemik är ju att beteckna min framställning såsom "183 I-grundtvigianisme", s. 746). Men vad är då t. ex. motsatsen till Grundtvig I 864? - Att laborera med så komplexa storheter som det här rör sig om är naturligtvis olämpligt när det gäller att få klarhet över problemkretsen mänskligt-kristet. Dessa tankeblock är otjänliga som analytiska instrument. I stället för att göra dylika enkla omvändningar och uteslutningsmanövrer är det fruktbarare att analysera själva problemkomplexen, som otvivelaktigt gömmer den väsentliga problematiken i Gr:s liv och författarskap. Det är detta jag sökt genomföra i boken "Mänskligt och kristet". Resultatet härav är icke det Thaning antyder med sin motsatskategori.

På denna punkt $\mathrm{i}$ framställningen torde det vara lämpligt att närmare ange hur våra tolkningar förhåller sig till varandra $\mathrm{i}$ stort. Det förhåller sig inte så att Thanings grundsyn är motsatt den jag redovisar i "Mänskligt och kristet". Redan där, på grundval av Thanings dåtida offentliggöranden och utifrån egen textanalys, formulerades följande ställningstagande: "Thanings bedömning av Grundtvigs utvecklingshistoria torde i huvudsak vara riktig. Hans tolkning av den systematiska innebörden kring vändpunkten I $83_{2}$ karakteriseras emel- 
lertid av en överbetoning av skapelsemomentet, som helt skiljes från frälsningen. Medvetandet om det polemiska i Grundtvigs uppgörelse med sig själv borde ju annars vara ett memento att låta även andra för ögonblicket ej så aktuella element komma till sin rätt. Grundtvigs senare författarskap visar att de finns där". (s. 247, jfr. även s.ıo, 38, 96, I 79, 1 86, 202 f., 224). - Thanings disputats bekräftar på ett slående sätt riktigheten av denna totalbedömning. Thaning har sett en väsentlig sida av Grundtvig, men har isolerat den på et sätt som gör det omöjligt att integrera den i en helhetsbild av Gr. Ambitionen att tesen skulle gälla hela Gr., såväl levnad som författarskap, har Thaning inte kunnat släppa och resultatet har blivit de påtalade förskjutningarna i metod, i tesens innebörd samt pseudoförklaringar och slutligen kapitulation inför de sista årens författarskap. Dessa uppenbara förhållanden hindrar inte Thaning att (i sin kommentar till ovan angivna text) säga, att den skarpa åtskillnaden av mänskligt och kristet "efterhånden" utvecklade sig "- netop i den senere del af forfatterskabet!" (s. 748).

Det är inte utan en känsla av obehag man går vidare $\mathrm{i}$ Thanings kritik. I stället för att klart söka ange det gemensamma och det som skiljer i resultat, frågeställningar och metod, tecknar Thaning två "motsatta" Grundtviguppfattningar. För att få motsatsen absolut isolerar han begrepp och uttryck $\mathrm{i}$ min bok från det sammanhang och den problematik där de hör hemma. Han drar sig inte heller för rena förtiganden och undertrycker texthänvisningar. För att diskussionsläget skall bli mera klart, är det nödvändigt att med några exempel påvisa hur Thaning kan dokumentera och argumentera.

På s. $75^{\circ}$ behandlar Thaning "livstolkning som forudsætning for kristendom", där det heter: "Det bånd, som Aronson vil bruge til at binde Grundtvigs tanker om det menneskelige og folkelige til teologien, er skabertroen. Men han må f. eks. helt hen til en begravelsestale i "Kirkelige Lejlighedstaler" for at finde bevis for, at skolen er til "for Menneskelivet i Guds Billede". - Går man nu till min bok, finner man att avsnittet "Skolan för livet" avses, där jag skisserar Grundtvigs uppfattning av skola och upplysning. Det heter där på s. 246: "Skolans egentligaste uppgift är att för den enskilda människan tolka det liv hon, i gemenskap med andra människor, faktiskt upplever. Skolan blir därför från början bestämd av miljö, skapas av de naturliga och historiska förutsättningarna, och riktar sig ständigt ut mot den givna miljön. Först i denna mänskligt-folkliga gemenskap 
kommer det allmänmänskliga till sin rätt. Endast härom kan skolan meddela en levande kunskap. ... Tendensen i skolskrifterna är att fixera och begränsa skolans uppgifter och målsättning. Detta sker med det vanliga, borgerliga livet för ögonen, dvs. livet såsom det leves av alla människor gemensamt i Danmark. Mot denna gemensamma nämnare, som den föreligger i den folkliga gemenskapen, är det skolans intresse skall inriktas. Dess uppgift är inte, och kan heller inte på grund av sin natur vara, av kyrklig art. (Hänvisning till Gr:s Taler paa Marielyst Højskole I856-187 I, utg. av Steen Johansen samt till Thanings position i skoldebatten). Jfr. vidare s. 252 i min bok med poängterandet av skolans borgerlighet och anpassningen till den sociologiska strukturen, "det fælles", och s. 257 med påpekandet av skillnaden mellan skolskrifterna på 30-talet och senare skoltankar. Sedan en redovisning skett av skoltankens framkomst, ordets betydelse och människosynen, ställes problemet hur den antropologi som kommer till uttryck i skolsynen förhåller sig till skapelsetanken. Jag hänvisar därvid till de mänskliga grundkategorierna (se sakregistret!) och fortsätter: "Grundtvigs skolprogram blir just genom den medvetna inriktningen på det allmänmänskliga mycket omfattande. En orienteringspunkt $\mathrm{i}$ den mänskliga mångfalden finner Grundtvig $\mathrm{i}$ skapelsetanken. Skolans verksamhet kan Grundtvig därför se som en verksamhet "for Menneske-Livet i Guds Billede". - I Thanings framställning blir nu allt detta kort och kategoriskt: "skolen er til for Menneske-Livet i Guds Billede". Det som hos mig så avgjort är en delaspekt, presenterar Thaning som det totala. Detta är hans genomgående polemiska grepp för att få fram en "motsats" till "Menneske først"-programmet (ytterst primitivt på s. 775, not 23; jfr. min bok s. I 39, I $79 \mathrm{f}, 187$ ). Parallellt med att sammanhanget förvanskas, förfar Thaning inkorrekt $i$ sin redovisning av mina belägg. Han säger att jag måste "helt hen til en begravelsestale (över Boisen augusti I862 ) för att finna bevis och förklarar, att när det där talas om "skola" är det inte fråga om det Gr. kallar skola (s. 774, not ro). Att jag också hänvisar till Gr:s Marielyst-tal från november r 862, med mycket starka uttryck (från skolans kateder på hans egen højskole!) för skapelsen till Guds avbild, förtiges. Så kan Thaning få möjlighet att säga: "I selve skoleskrifterne er Skaberen nemlig ikke fremme". - Formuleringen är listig. Thaning vill uppenbarligen eliminera samlingen av Marielyst-tal, som ej är "skoleskrift" i teknisk mening, efter som de i samlad form tryckts först hundra år efteråt. 
Förtigandet fyller denna funktion, liksom införandet av termen "skoleskrift". I Marielyst-talen har vi emellertid Grundtvigord från talarstolen på den skola som skulle ge honom just en möjlighet att förverkliga sin egen højskoletanke och dessa tal är därför i eminent grad relevanta och viktiga i sammanhanget. Samlingen sträcker sig också över en tidrymd av femton år, I856-187I. - Skaparen och skapelsetanken är här framma i tal efter tal (se s. 5, 7, 8, 9, I o, I I, I4, I 7, I 8, 25, 27, 28, 52, 55, 6o, 74, 80, 89). Förutom på s. 6r ( I862) dit jag hänvisar i min bok, förekommer uttrycket "skabt i Guds Billede" även på s. 52 och s. 55 ( 186o, I859). Talen är för övrigt fyllda av mytologiska och andra utsagor om det mänskligt-folkliga, typiska för Gr:s antropologi. Om språket heter det: "Der er sex Ord, Par om Par, altsaa tre Par Ord, som man finder i ethvert Tungemaal, som skal due til at oplyse Menneske-Livet heelt og holdent, som det er, og som Erfaringen har lært os, og skal bestandig bedre lære os at kiende det, og disse tre Par Ord er "Lys og Morke" saa "Liv og Død" og endelig "Sandhed og Løgn" (s. 25). Sammankopplingen av det genom erfarenheten upplevda och det dualistiska betraktelsesättet är här mycket markant. (Vad Thaning säger om liv-dödmotsättningen på s. 749 i sin bok är felaktigt och måste framstå såsom rent nonsens för var och en som har kännedom om Gr.). Gr. ger med andra ord i dessa tal rikt varierade uttryck för sin människosyn. När Thaning förtiger min hänvisning till denna källa, undertrycker han ett element som är helt avgörande för frågeställningarna hos oss båda. Om man tillåter sig en dylik utsortering av besvärande källor, är det naturligtvis lätt att leverera kritik. Det är ju emellertid inte betecknande bara för Thanings polemik. Överhuvudtaget förfar han ju selektivt i sin källvärdering.

Helt kan Thaning emellertid inte förbigå dessa källor i sin egen framställning. Under rubriken 'Marielyst-taler' tas en del upp (s. 4I3-4I7). Thaning ser att dessa texter går emot hans tes ("Grundtvig misforstår sig selv", s. 416, det tales om "uklarhed" s. 4I5, 4I7). Några av texterna är t. o. m. så motspänstiga att de föres över till själva slutpartiet (s. $73^{8}$ ff.), där frågan ställes om Gr. förlorade det fasta greppet på sitt gamla grundproblem. Thaning måste där till slut konstatera att "klarheden var glippet". Thaning påstår därvid också (s. 740) att han gjort reda för alla de problematiska ställena i den sista delen av Gr:s produktion. - Det förhåller sig inte så. På s. 415, översta stycket, förklarar Thaning svårighe- 
terna med kriget i 864, som "synes at have bragt ham til at tale mere om kristendommen i folkelige sammenhænge end før”. Det förhåller sig emellertid så, att texterna ur Thanings synpunkt är problematiska långt före 864 ! Hela framställningen är emellertid skriven så att läsaren skall tro att det blir svårt för tesen först $\mathrm{i}$ och med I 864. Att läsa Marielyst-talen med Thanings tes som slagruta är överhuvudtaget inte möjligt. Dessa texter vittnar mot Thaning. Eftersom de föreligger i en lätt tillgänglig utgåva kan envar övertyga sig därom.

Det kan anföras en lång rad texter som går emot Thaning. Det kan också anföras en rad temata som ej går att få in i hans tolkning. Ett annat argument, lika viktigt om än inte lika dramatiskt, är att tesen ( $\mathrm{i}$ den extrema form den föres fram $\mathrm{i}$ disputatsen) inte behöves. Det är en klassisk princip vid vetenskapligt arbete att inte göra flera antaganden än som behöves. I sin genomgång av artikeln "Moses og Jesus" i Dansk Kirketidende ı 852 (s. 648-65o) säger Thaning att Grundtvig här "... tog det problem op fra grunden, som han i 1832 fik et helt nyt syn på ...”. Genomgången avslutas med en omständlig kommentar, där det säges att det etiska perspektivet försvinner i Grundtvigs utläggning av Moses och Jesus (s. 65o). - Just i denna artikel har man emellertid starka uttryck för Grundtvigs tolkning av lagen såsom en skapelsens lag. Det historiskt-poetiska bär i sig en sådan lag. Starkt framhäves här de mänskliga grundkategorier Grundtvig förutsätter för att evangeliet skall kunna uppfattas (se a. a. 715, jfr Danskeren IV s. 90, 318, 6o8, Dansk Kirketidende 1854 s. 480 samt Mänskligt och kristet s. 235 ff). Dessa så viktiga formuleringar redovisas ej av Thaning. De försvinner, emedan de ej passar till den teologiska grundkonception han arbetar med. Ändå är dessa formuleringar av de "grundmenneskelige Livs-Forhold" en bärande tankeskapelse i Grundtvigs teologi, som man mycket väl kan karakterisera med ordningsföljden lag-evangelium, eller mera grundtvigskt: mänskligt och kristet. I min Grundtviginterpretation intar dessa element en framträdande plats, hos Thaning försvinner de. Om någon vill göra en direkt jämförelse mellan vad jag får ut av en text utifrån mina utgångspunkter och vad Thaning får ut, utrustad med sin tes, är det lämpligt att läsa just sidorna $648-65^{\circ}$ hos Thaning och sidorna 227-236 i "Mänskligt och kristet", där vi båda behandlar just texten "Moses og Jesus". Texten är teologiskt klar och typisk för I850-talets Grundtvig. Den visar en klar åtskillnad 
och ett klart sammanhang mellan mänskligt och kristet. Att se den utifrån "I 832" är överflödigt och leder till att texten dels pressas, dels avkortas. Tar man texten som den är och uppfattar de klassiska teologiska frågeställningar, den behandlar, får man också här fram en karakteristisk bild av Grundtvig.

Det bestående $\mathrm{i}$ dr. Thanings stora disputats är påvisandet av tendenser $\mathrm{i}$ en vis fas av Grundtvigs utveckling, tendenser som slår ut $\mathrm{i}$ Grundtvigs energiska arbete för en pluralistisk kultursyn. Till det bestående måste också räknas en lång rad förträffliga detaljanalyser och enskilda iakttagelser. Dr. Thaning visar inte sällan upp en fin Fingerspitzgefühl, när han söker efter nerven $i$ "Grundtvigs opgør med sig selv". A andra sidan är han alldeles okänslig för andra element hos Grundtvig, alldeles omedveten om metodfrågornas betydelse och särdeles brutal - också sakligt sett - i "opgøret" med andra.

Bjørnson lyste inte frid vid Grundtvigs grav, men strid: ". . mens der ved andre Grave lyses Fred, bør der lyses Kamp over denne! Kamp for det, vi elske, og elske ved ham!'” - Dr. Thanings litterära livsverk är ett svar på denna maning. Det är inte ett akademiskt svar, men ett personligt. Men såsom sådant är det i särskild grad engagerande. Vilket också betyder att kampen fortsätter! 